\title{
HASIL KETERAMPILAN LOMPAT JANGKIT (Studi Eksperimen Menggunakan Latihan Plyometrik)
}

\author{
Akhmad Sobarna ${ }^{1}$, Sumbara Hambali ${ }^{2}$, Rony Mohamad Rizal ${ }^{3}$, \\ Lingga Sevtiadzi ${ }^{4}$ \\ ${ }^{1}$ Dosen Program Magister Pendidikan Jasmani, ${ }^{2}$ Dosen Prodi PJKR , ${ }^{3}$ Dosen Program Magister \\ Pendidikan Jasmani STKIP Pasundan, Jalan Permana 32B Citeureu, Cimahi Utara \\ Email: akhmadsobarna9@gmail.com
}

\begin{abstract}
Abstrak
Penelitian ini menggunakan studi eksperimen dengan tujuan untuk mengetahui pengaruh latihan plyometrik lompat dua terhadap keterampilan lompat jangkit. Populasi penelitian yaitu mahasiswa STKIP Pasundan Cimahi tingkat I yang berjumlah 196 orang. Sampel penelitian berjumlah 60 orang yang diperoleh dengan teknik cluster random sampling. Teknik pengumpulan data yang digunakan adalah dengan tes keteramplan (performance test) yaitu tes lompat jauh. Selanjunya dana penelitian dianalisis dengan menggunakan teknik analisis statistik dengan menggunakan aplikasi SPSS versi 16. Sebelum dinalisis, dilakukan uji persyaratan analisis yaitu uji normalitas menggunakan one-sample Kolmogorov-Smirnov test dan uji homogenitas menggunakan Levene's test. Hasil uji persyaratan analisis menunjukkan bahwa data pre test dan post test berdistribusi normal dan homogen. Berdasarkan hasil analisis data dan pengujian hipotesis uji paired sample $t$ test diperoleh simpulan bahwa terdapat pengaruh latihan plyometrik lompat dua terhadap keterampilan lompat jauh pada mahasiswa STKIP Pasundan Cimahi.
\end{abstract}

Kata Kunci: latihan plyometric, lompat jangkit

\begin{abstract}
This study uses an experimental study with the aim to determine the effect of double jump plyometric exercises on outbreak jumping skills. The study population is 196 students of STKIP Pasundan Cimahi. The research sample of 60 people were obtained by cluster random sampling technique. The data collection technique used is the performance test, which is the long jump test. Further research funds were analyzed using statistical analysis techniques using the SPSS application. Before the analysis, the analysis requirements test is done, namely the normality test using the Kolmogorov-Smirnov one-sample test and the homogeneity test using the Levene's test. The results of the analysis requirements test show that the pre-test and post-test data are normally distributed and homogeneous. Based on the results of data analysis and hypothesis testing of paired sample t test, it was concluded that there is an effect of two jump plyometric exercises on long jump skills in Pasundan Cimahi STKIP students.
\end{abstract}

Keywords : exercise plyometric, triple jump.

\section{PENDAHULUAN}

Pendidikan jasmani merupakan bagian dari pendidikan di sekolah yang melibatkan kegiatan jasmani. Peserta didik dapat lebih banyak belajar hal yang berhubungan dengan pendidikan jasmani yang dapat di kembangkan peserta didik. Santos (2017: 294) menyatakan bahwa pendidikan jasmani adalah untuk 
mempromosikan kesehatan dan melatih siswa untuk aktivitas fisik secara teratur di waktu luang mereka, untuk melanjutkan aktivitas fisik ke masa dewasa dan mengarah pada penerapan kebiasaan latihan yang memiliki dampak positif pada kesehatan dan kualitas hidup. Pelaksanaan pendidikan jasmani di sekolah harus memberikan pendidikan yang positif dan sangat dibutuhkan oleh peserta didik. Pendidikan jasmani selain bertujuan untuk meningkatkan kualitas diri peserta didik dalam aktivitas olahraga, juga untuk mengembangkan kebugaran jasmani.

Dalam kegiatan pendidikan jasmani di sekolah ternyata memberikan kesempatan kepada peserta didik untuk mengembangkan nilai-nilai pribadi melalui partisipasi dalam aktivitas jasmani baik secara kelompok maupun perorangan jasmani bahwa. Pendidikan jasmani merupakan bagian integral dari pendidikan secara keseluruhan (Harsono, 2017: 85-91). Tujuannya untuk mengembangkan aspek kebugaran jasmani, keterampilan gerak, keterampilan berpikir kritis, keterampilan sosial, penalaran, stabilitas emosional, tindakan moral, aspek pola hidup sehat dan pengenalan lingkungan bersih, melalui aktivitas jasmani, olahraga, dan kesehatan terpilih yang direncanakan secara sistematis dalam rangka mencapai tujuan pendidikan nasional.

Berbeda dengan pendidikan jasmani di sekolah, di bangku perguruan tinggi khususnya dalam jurusan pendidikan jasmani justru lebih dalam mempelajari olahraga. Untuk membentuk perkembangan dan pertumbuhan siswa serta mengenalkan nomor-nomor cabang olahraga atletik itu, untuk membantu perkembangan dan keterampilan gerak dasar khususnya pembentukan gerak dasar atletik yang sangat kurang di dalam pembelajaran atletik di bangku perkuliahan juga siswa dituntut untuk bisa mengetahui semua cabang olahraga, sebab siswa di perguruan tinggi itu akan menjadi pendidik. Oleh sebab itu siswa harus tau cabang-cabang olahraga dari beberapa cabang olahraga atletik. Penelitian ini akan mengkaji dan meneliti tentang pengaruh plyometrik terhadap hasil lompat jangkit pada perkuliahan pembelajaran atletik di STKIP Pasundan Cimahi yang dikarenakan siswa di perkuliahan atletik hasil lompat jangkit kurang begitu bagus. 
Wirianto (2011: 45-46) mengatakan lompat jangkit adalah suatu bentuk gerakan yang merupakan rangkaian urutan gerakan yang dilakukan dengan teknik awalan (sprint), berjingkat (hop), melangkah(step), dan melompat (jump) dalam usaha untuk mencapai jarak sejauh-jauhnya. Lompat rangkap adalah lintasan dan medan yang tujuannya adalah untuk mencapai jarak horizontal maksimum. Tidak seperti dalam lompat jauh, di mana tujuannya adalah untuk mengerahkan upaya maksimal untuk mencapai jarak terbesar, lompat ganda adalah gerakan kompleks yang terdiri dari tiga fase terpisah namun terpisah yang dilakukan dalam upaya untuk memaksimalkan jarak gabungan dari ketiganya (Wilson, 2009: 4-5).

Kontak-kontak tanah yang mendahului fase-fase hop, step, dan jump sebagian besar menentukan jarak penerbangan dalam setiap fase dan telah disarankan bahwa transisi, atau kontak, antara fase hop dan fase adalah elemen paling penting dalam keberhasilan lompat ganda yang sukses. Latihan adalah untuk membantu dan meningkatkan keterampilan dan prestasinya semaksimal mungkin (Harsono, 2017). Latihan adalah proses penyempurnaan berolahraga melalui pendekatan ilmiah khususnya prinsip-prinsip pendidikan, secara teratur dan terencana sehingga mempertinggi kemampuan dan kesiapan (Kalfi, 2013: 3940).

Ada empat aspek utama yang perlu di persiapkan dalam melakukan pelatihan keterampilan cabang olahraga, yaitu (1) persiapan fisik: (1) persiapan teknik, (2) persiapan taktik, (3) persiapan psikologis (Azahra, 2015: 68-69). Ke empat aspek tersebut memiliki kedudukan yang sama penting meskipun masingmasing aspek memiliki persentase yang berbeda-beda sesuai dengan kondisi dan tingkat kemampuan masing-masing individu. Aspek aspek tersebut tersusun secara hierarkhi, sehingga aspek fisik merupakan salah satu aspek penting yang harus diperhatikan pertama sekali. Dari pengertian para ahli di atas dapat dipahami dan di simpulkan bahwa latihan hendaknya sistematik, berurutan dari beban yang ringan hingga beban yang berat. Jadi latihan tidak bisa langsung kepada beban yang berat, akan tetapi harus memperhatikan prinsip-prinsip latihan yang baik dan benar. Latihan plyometric melatih serabut otot cepat dan saraf 
mengaktifkan mereka serta refleks karenanya itu adalah salah satu alat utama yang meningkatkan baik itu kekuatan dan kecepatan.

Dalam metode plyometric semua latihan atau kegiatan yang tujuannya adalah untuk meningkatkan reaksi ledakan pemain melalui kontraksi otot yang kuat. Peningkatan reaksi eksplosif terjadi sebagai akibat dari kontraksi eksentrik yang cepat (Harmandeep, 2011: 3-4). Latihan plyometric yang diberikan pada seorang atlet secara kuantitatif dapat meningkatkan kekuatan vertical lompatan, daya ledak otot tungkai, kemampuan melompat lebih tinggi dan merubah arah dengan cepat (Morre, 2017). Melompat, berlari, dan melompat-lompat yang menggunakan siklus peregangan peregangan dari unit otot secara konsisten telah ditunjukkan untuk meningkatkan produksi kekuatan otot dan kekuatan.Secara khusus, produksi kekuatan cepat dari otot yang terlatih membaik, ditambah dengan peningkatan yang lebih kecil dalam kekuatan isometrik maksimum. Oleh sebab itu siswa harus mengetahui cabang-cabang beberapa cabang olahraga atletik. Penelitian ini akan mengkaji dan meneliti tentang pengaruh plyometrik terhadap hasil lompat jangkit pada perkuliahan pembelajaran atletik di STKIP Pasundan, karena siswa diperkuliahan atletik hasil lompat jangkit kurang begitu bagus.

\section{METODE}

Desain penelitian yang digunakan adalah metode penelitian eksperimen dengan desain pre test post tes control group design (Tabel 1).

Tabel 1. Rancangan penelitian pre test-post test group design

\begin{tabular}{cccc}
\hline Kelompok & Pre-Test & Perlakuan (X) & Posttest \\
\hline Eksperimen & Y1 & $\mathrm{X} 1$ & Y2 \\
Kontrol & $\mathrm{Y} 2$ & $\mathrm{X} 2$ & $\mathrm{Y} 2$ \\
\hline
\end{tabular}

Penelitian eksperimen ini bermaksud untuk mengetahui dan memperoleh gerak dasar lompat jangkit antara kelas yang menerapkan latihan pliometrik denag lompat dus dan tanpa lompat dus pada mahasiswa STKIP Pasundan. 
Populasi dalam penelitian ini seluruh mahasiswa tingkat I yang mengikuti perkuliahan atletik sebanyak 196 orang. Pengambilan sampel dilakukan dengan teknik cluster random sampling sehingga diperoleh 60 orang sebagai sampel penelitian (30 orang Kelas D sebagai kelompok eksperimen, dan 30 orang Kelas A sebagai kelompok kontrol).

Instrumen yang digunakan untuk mengukur lompat jauh adalah tes lompat jauh yang sudah di uji keterbacaan, uji validitas dan uji reliabilitas. Adapun hasil uji terlihat pada Tabel 2.

Tabel 2 Hasil uji reliabilitas instrumen lompat jauh

\begin{tabular}{ccc}
\hline Corbach's & $\begin{array}{c}\text { Cronbach's alpha based } \\
\text { on standardizes items }\end{array}$ & N of items \\
\hline 0,838 & 0,720 & 9 \\
\hline
\end{tabular}

Dari hasil uji reliabilitas dapat menunjukan bahwa nilai $\mathrm{p}=0,720$, artinya p>0.05 kesimpulannya instrumen lompat jangkit memiliki tingkat reliabel yang tinggi. Teknik analisis data yang digunakan adalah uji Paired Sample T-Test bertujuan untuk menguji ada tidaknya perbedaan mean untuk dua kelompok yang berpasangan. Subjeknya sama, namun mengalami dua perlakuan atau pengukuran yang berbeda. Uji Independent-Samples T-Test bertujuan untuk membandingkan rata-rata duakelompok. Teknik analisa menggunakan program Statistical Product for Social Science versi 16.

\section{HASIL DAN PEMBAHASAN}

\section{Hasil}

Berdasarkan hasil perhitungan data, maka diperoleh nilai rata-rata dan simpangan baku dari 30 responden (Tabel 3).

Tabel 3 Hasil Hitung Rata-rata dan Simpangan Baku Deskripsi Statistik

\begin{tabular}{lccc}
\hline \multicolumn{1}{c}{ Keterangan } & N & Mean & SD \\
\hline Tes Awal Keterampilan Lompat Jangkit Kelompok Eksperimen & 30 & 26,16 & 3,42 \\
Tes Akhir Keterampilan Lompat Jangkit Kelompok Eksperimen & 30 & 29,00 & 3,49 \\
Tes Awal Keterampilan Lompat Jangkit Kelompok Kontrol & 30 & 25,06 & 2,86 \\
Tes Akhir Keterampilan Lompat Jangkit Kelompok Kontrol & 30 & 27,16 & 2,87 \\
\hline
\end{tabular}


Berdasarkan Tabel 3, didapatkan skor rata-rata untuk tes awal keterampilan lompat jangkit pada kelompok eksperimen lebih tinggi dibandingkan dengan skor rata-rata tes akhir pada kelompok kontrol.

Dalam pengujian normalitas distribusi data ini, penulis perlu menetapkan bahwa seluruh data berdistribusi normal atau tidak normal. Pengujian normalitas data menggunakan rumus uji normalitas hasilnya disajikan pada tabel 4.

Tabel 4 Hasil Uji Normalitas One-Sample Kolmogorov-Smirnov Test

\begin{tabular}{|c|c|c|c|c|c|}
\hline & \multirow{2}{*}{$\begin{array}{c}\text { T1 } \\
\text { Kelompok } \\
\text { Eksperimen }\end{array}$} & \multirow{2}{*}{$\begin{array}{c}\text { T2 } \\
\text { Kelompok } \\
\text { Eksperimen }\end{array}$} & \multirow{2}{*}{$\begin{array}{c}\text { T1 } \\
\text { Kelompok } \\
\text { Kontrol } \\
\end{array}$} & \multirow{2}{*}{$\begin{array}{c}\text { T2 } \\
\text { Kelompok } \\
\text { Kontrol } \\
\end{array}$} \\
\hline & & & & & \\
\hline $\mathrm{N}$ & & 30 & 30 & 30 & 30 \\
\hline Normal & Mean & 26,16 & 29,20 & 25,06 & 27,16 \\
\hline Parameter & SD & 3,07 & 3,14 & 2,76 & 2,77 \\
\hline Most & Absolute & 0,17 & 0,18 & 0,20 & 0,13 \\
\hline Extreme & Positive & 0,13 & 0,18 & 0,19 & 0,13 \\
\hline Difference & Negative & $-0,177$ & $-0,16$ & $-0,20$ & $-0,13$ \\
\hline \multicolumn{2}{|c|}{ Kolmogorov-Smirnov } & 0,971 & 1,02 & 1,12 & 0,72 \\
\hline \multicolumn{2}{|c|}{ Asymp.Sig (2-tailed) } & 0,30 & 0,25 & 0,16 & 0,68 \\
\hline
\end{tabular}

Berdasarkan data yang diperoleh dari perhitungan uji normalitas pada Tabel 4, dapat dilihat bahwa nilai Asymp. Sig. (2-tailed) tes awal dan tes akhir kelompok eksperimen dan kelompok kontrol lebih besar dari 0,05 sehinga dapat disimpulkan bahwa semua data berdistribusi normal.

Langkah berikutnya untuk persyaratan pengujian statistik adalah uji homogenitas. Pengujian ini menggunakan Levene's test. Pengujian dilakukan melalui SPSS 16, berikut hasil pengujian homogenitas yang dapat dilihat pada Tabel 5.

\begin{tabular}{cccc}
\multicolumn{4}{c}{ Tabel 5 Hasil Uji Homogenitas Kelompok A } \\
\hline Levene Statistic & Df1 & Df2 & Sig \\
\hline 0,217 & 7 & 21 & 0,977 \\
\hline
\end{tabular}

Nilai hasil pengujian homogenitas dari variabel tes awal dan tes akhir kelompok B menggunakan Levene's Test menunjukan angka sebesar 0,977 pada sig. lebih besar dari 0,05 (signifikansi > 0,05) Artinya, data dalam keadaan homogen. 
Uji Paired Sample T-Test yang digunakan bertujuan untuk menguji ada tidaknya perbedaan mean untuk dua kelompok yang berpasangan. Subjeknya sama, namun mengalami dua perlakuan atau pengukuran yang berbeda.

Tabel 6 Paired Samples Test

\begin{tabular}{|c|c|c|c|c|c|c|c|c|c|}
\hline & & \multicolumn{5}{|c|}{ Paired Differences } & \multirow[t]{3}{*}{$t$} & \multirow[t]{3}{*}{$d f$} & \multirow{3}{*}{$\begin{array}{l}\text { Sig. }(2 . \\
\text { Tailed })\end{array}$} \\
\hline & & \multirow[t]{2}{*}{ Mean } & \multirow[t]{2}{*}{$\begin{array}{c}\text { Std. } \\
\text { Deviation }\end{array}$} & \multirow[t]{2}{*}{$\begin{array}{l}\text { Std. } \\
\text { Error } \\
\text { Mean }\end{array}$} & \multicolumn{2}{|c|}{$\begin{array}{l}\text { 95\% Confidence } \\
\text { Interval of the } \\
\text { Difference }\end{array}$} & & & \\
\hline & & & & & Lower & Upper & & & \\
\hline $\begin{array}{c}\text { Pair } \\
1\end{array}$ & $\begin{array}{c}\text { VAR0 } \\
\text { 0023- } \\
\text { VAR0 } \\
0026 \\
\end{array}$ & -266667 & 1,64701 & 0,3007 & -328167 & $-2,05166$ & $-8,868$ & 29 & 0,00 \\
\hline $\begin{array}{c}\text { Pair } \\
2\end{array}$ & $\begin{array}{l}\text { VAR0 } \\
\text { 0024- } \\
\text { VAR0 } \\
0027\end{array}$ & $-2,1$ & 0,75886 & $\begin{array}{c}0,1385 \\
5\end{array}$ & $-2,38336$ & $-1,81664$ & $-15,16$ & 29 & 0,00 \\
\hline
\end{tabular}

Keterangan:

Berdasarkan tabel 6 diketahui bahwa nilai signifikansi untuk kelas eksperimen dan kelas kontrol lebih kecil dari 0,05 berarti $\mathrm{H}_{\mathrm{o}}$ ditolak. Hal ini menunjukkan bahwa ada perbedaan peningkatan hasil belajar antara tes awal dan tes akhir pada mahasiswa yang diterapkan pembelajaran menggunakan latihan plyometric dan ada perbedaan penurunan hasil belajar lempar lembing antara tes awal dan tes akhir siswa yang diterapkan pembelajaran lompat jangkit tanpa menggunakan latihan plyometric.

\section{Pembahasan}

Berdasarkan hasil penelitian dengan menggunakan Uji Paired Samples Terdapat pengaruh dalam Pembelajaran lompat jangkit menggunakan latihan plyometrik lompat dus terhadap hasil belajar lompat jangkit dengan kata lain, latihan tersebut berpengaruh secara signifikan terhadap hasil belajar lompat jangkit dan bisa di pakai sebagai bahan pembelajaran lompat jangkit. Dalam penelitian ini menggunakan kompetisi untuk membentuk dan mengembangkan motivasi belajar kepada siswa melalui pembelajaran lompat jangkit dengan menggunakan latihan plyometrik lompat dus, sejalan dengan pernyataan Layne (2014), consider a few characteristics of when competition becomes the 
motivation: focusing on goals being scored instead of on the process of scoring, becoming upset when a student misses a scoring opportunity either through shooting or passing to a teammate, or configuring the team toward the best players. Ketika siswa bermain dalam situasi kompetitif ketika pembelajaran penjas, maka disitulah motivasinya akan ikut berkembang.

Plyometric adalah suatu latihan-latihan yang menghasilkan gerakan otot isometric yang berlebihan yang memberikan reflex dalam otot, plyometrik ditujukan untuk latihan yang menggunakan gerakan otot-otot untuk menahan beban keatas dan menghasilkan power dan kekuatan eksplosif. Pada intinya plyometrick adalah serangkaian latihan potensial maksimalnya dalam waktu yang sesingkat mungkin. Turgay, Ozgur (2012) menyatakan bahwa Building strong muscles are developing body resistance. Developing body resistance depends on a specific outcome like as muscular endurance, maximal strength, or power. Karena kecepatan dan kekuatan merupakan komponen integral dalam olahraga, perpaduan antara keduanya, yang disebut dengan tenaga atau daya.

Pendapat di atas memberikan gambaran bahwa latihan plyometric sangat sesuai dan tepat untuk meningkatkan daya ledak otot tungkai. Plyometric training is popular among individuals involved in dynamic sports, and plyometric exercises such as jumping, hopping, skipping and bounding are executed with the goal of increasing dynamic muscular performance, especially jumping. Daya ledak otot tungkai adalah faktor yang sangat penting dalam cabang olahraga atletik khususnya nomor lompat jangkit. Bentuk latihan plyometrik yang baik untuk latihan kekuatan tungkai di antaranya squat jump, lompat boks, squat jump dengan lutut

Berdasarkan hasil penelitian dengan menggunakan uji Paired Samples diketahui bahwa tidak terdapat pengaruh yang signifikan dalam pembelajaran lompat jangkit tanpa menggunakan latihan plyometric lompat dua. dengan kata lain pembelajaran tersebut kurang adanya penerapan teknik lompat jangkit dengan menggunakan latihan plyometrik, karena dalam cabang olahraga Atletik nomor lompat jangkit ini adalah nomor teknik yang lebih dominan, karena latihan teknik lompat jangkit menggunakan latihan plyometric lompat dua 
berpengaruh secara signifikan terhadap hasil belajar lompat jangkit dan bisa di pakai sebagai bahan Pembelajaran lompat jangkit.

\section{SIMPULAN}

Program latihan plyometrik menggunakan lompat dus memberikan pengaruh yang signifikan terhadap hasil lompat jangkit pada mahasiswa STKIP Pasundan Cimahi. Program latihan plyometrik menggunakan lompat dus terdapat pengaruh yang signifikan.Latihan tanpa menggunakan lompat dus memberikan pengaruh yang signifikan terhadap hasil lompat jangkit pada mahasiswa STKIP Pasundan Cimahi. Latihan tanpa menggunakan dus tidak terdapat pengaruh yang signifikan. Dari hasil penelitian, yang lebih berpengaruh terhadap latihan plyometric yaitu latihan plyometric menggunakan lompat dua.

\section{DAFTAR PUSTAKA}

Harsono. 2017. Latihan Kondisi Fisik. Bandung: Senari Pustaka.

Layne dan Todd, E. 2014. Competition within Physical Education: Using Sport Education and Other Recommendations to Create a Productive, Competitive Environment, Strategies. Journal for Physical and Sport Educators, 27 (6), 3-7, DOI: 10.1080/08924562.2014.960124.

Turgay dan Ozgur. 2012. Muscle Power And Strength Performance In Sport. International Journal of Basic and Clinical Studies (IJBCS), 1 (9), 41-55.

Wilson, C. 2009. Movement Coordination Pattems in Triple Jump Training Drills. Journal of Sport Sciences, 27 (3), 277-282.

Kalfi, R. 2013. Pengaruh Latihan Plyometric Hurdle Hopping dan Depth Jump terhadap Peningkatan Vertical Jump Bola Voli Club JIB Kids Bantul. Skripsi. Yogyakarta: UNY 